\title{
Coordination or Dominance of Fiscal and Monetary Policy in Egypt
}

\author{
Emad Omar Elhendawy ${ }^{1}$ \\ ${ }^{1}$ University of Jeddah, College of Business at Khulis, Department of Finance, Jeddah, Saudi Arabia \\ Correspondence: Emad Elhendawy, Associate Professor, University of Jeddah, College of Business at Khulis, \\ Department of Finance, Jeddah, Saudi Arabia. Tel: 966-365-300-5205. E-mail: \\ eoali@uj.edu.sa/emad_elhendawy_2006@hotmail.com
}

Received: October 1, 2019

Accepted: November 1, 2019

Online Published: November 6, 2019

doi:10.5539/ijef.v11n12p28

URL: https://doi.org/10.5539/ijef.v11n12p28

\begin{abstract}
This study investigates to what extent of coordination between the fiscal and monetary policies in Egypt in the period 1980-2017, it has been adopted in its methodology on the vector error correction and Granger causality test. It concludes that there is a significant relation between money supply and budget deficit on one hand and inflation on the other hand, and that fiscal policy is dominant in monetary policy, as a change of $10 \%$ of the budget deficit results in an increase in the inflation rate of $8.1 \%$. As for the Granger causality test. Thus stresses the existence of causal relationship to one direction of inflation against both the budget deficit and the money supply, which affects the budget deficit in the second slowdown. Then it feeds the budget deficit and inflation in the third year, which in turn feeds the budget deficit in the fourth year and the causal relationship between inflation and money supply has concluded that there is a one-way causal relationship of money supply to inflation after four slows and then inflation affects the money supply from the fifth to the tenth slowdown. As for the relationship of the budget deficit to money supply, there may be a one-way causal relationship between the budget deficit and the money supply from the second to the tenth year, except the third year, which also confirms the dominance of fiscal policy on monetary policy in Egypt in the period under consideration.
\end{abstract}

Keywords: fiscal policy, monetary policy, VEC, Granger causality test, Egypt

\section{Introduction}

Coordination between fiscal and monetary policies means that arrangements are in place to ensure that the decisions of the fiscal and monetary authorities are not contradictory, meaning that if one authority makes a decision it will not indirectly affect other policy objectives (Begg et al., 2003). The Keynesian theory gave fiscal policy an important role in the macroeconomic impact after World War II, emphasizing that fiscal expansion had positive effects on production and employment through its impact on aggregate demand. The 1960s governments relied on spending and taxes to implement stabilization policies. In the late 1960s, monetary policy emerged as a political tool of equal importance, Monetary and fiscal policy were used simultaneously to achieve internal and external balance until recessionary inflation emerged in the 1970s, reducing the role of fiscal policy and monetary policy becoming the main policy instrument (Taylor, 2000, 2009; Calmfors, 2003; Blanchard et al., 2010). On the other hand, two major economic issues have raised the growing interest in the effectiveness of fiscal policy in achieving economic stability: the creation of the European Monetary Union (EMU) in the 1990s and the global fiscal and economic crisis that began in September 2008. In the first case, The European Central Bank (ECB) adopts an independent monetary policy, as no EU Member State can adjust interest rates or exchange rates, so the fiscal policy of each EU country is the only instrument available to stabilize output, (Beryson, 1994; Beetsma et al., 2001; and Calmfors, 2003). In the second case, the global fiscal and economic crisis, monetary policy has failed to deal with a sharp economic downturn under interest rates, which was almost zero and fiscal policy alone was the one to shoulder the burden of restoring economic stability (Feldstein, 2009; Blanchard et al., 2010).The fiscal and monetary policies have a mutual influence on each other because they operate in a single economic environment. Monetary policy decisions affect some variables that have an important impact on fiscal policy, such as short-term interest rates, inflation, expectations, and risk premium that have an impact on prices Long-term interest. As an effect on interest rates has an impact on government debt and the burden of servicing this debt. In addition, inflation reduces the real value of government revenue, especially taxes, which may have the effect of Olivera-Tanzi on Fiscal sustainability of fiscal policy. The attempts by central banks to intervene in order to increase the volume of reserves from sterile intervention increase the burden of public debt service (Elhendawy, 
2015; Lee, 1996). Fiscal policy also has a direct and indirect effect on inflation. The large fiscal deficit affects inflation directly if it is financed by the new monetary instrument, but if it is financed by loans, however, the volume of bank loans directed to private sector investment is reduced, crowding-out effect, which will have a negative impact on economic growth and also affects inflation in the future. The fiscal policy indirectly affects inflation. Therefore if the fiscal deficit is financed by indirect taxes (VAT and general sales tax, for example), the cost of production increases and expectations play a large role in the spiral effect between producer's prices and owners' which increases inflation due to costs. The chronic budget deficit and the consequent increase in public debt servicing burdens have a significant impact on the balance of payments deficit (Elhendawy, 2014), thus affecting exchange rates and increasing inflation. Moreover, increasing the public debt service burden resulting from sterile intervention which has an impact on future inflation rates (Elhendawy, 2015). The renewed interest in the role of fiscal policy in economic stabilization has raised the issue of the need for coordination between monetary and fiscal policy, This issue has been discussed in the light of the potential inflationary effects of budget deficits, especially when this deficit is financed by the new money issue; it illustrates the relationship between fiscal and monetary policy so that fiscal policy has a clear role in demand management.

However, the need for coordination goes beyond these issues and is based on many other arguments as well: First of all, monetary and fiscal policies are carried out by two separate authorities, central bank and the fiscal authorities, whose inconsistent decisions may lead to a combination of sub-optimal economic outcomes, both in terms of inflation and output (low output and rising prices). Secondly, monetary and fiscal authorities have different objectives or assign different weights to common economic objectives. For example, central banks place greater weight on inflation relative to stability in output, which is the primary objective of fiscal policy. Thirdly, fiscal policy may undermine the monetary policy committee to inflation targeting, because the pre-response function of the fiscal authority by increasing the budget deficit completely negates the advantages of monetary committee by targeting inflation (Alnetina \& Tabellini, 1987; Benbert \& Loayza, 2002; Lambertini \& Rovelli, 2004). Lack of fiscal sustainability and high levels of debt undermine the effectiveness of monetary policy, either directly or through expectations of uncontrolled inflation (Eusepi \& Preston, 2008). Fourthly, fiscal policy is important for the credibility of monetary policy because increasing the budget deficit in terms of the central bank's interaction with periodic output movements harms the credibility of monetary policy; therefore, monetary policy and fiscal policy should be coordinated with regard to the stability of output (Taylor, 2000). Moreover, fiscal and monetary coordination is necessary in attempts to fully reverse inflation because the low rates of monetary growth under a certain level of inflation lead to a decrease in revenues from taxes, which is considered the most important item of revenue for the budget of the state and may resort to increasing rates, taxes or cuts in budget expenditures and further economic contraction, which may not be necessary to concede high inflation rates. Fifthly: Both fiscal and monetary policies affect the exchange rate and real interest rates, which affect both domestic consumption and net exports, the ratio between government spending and private investment, aggregate demand and output. (Kuttner, 2002; Lambertini \& Rovelli, 2004). Sixthly: Coordination between fiscal and monetary policies is necessary when the global financial and economic crisis occurs, were Nominal interest rates have fallen to zero so traditional monetary policy has become ineffective as central banks cannot cut them further, Developed economies have relied on fiscal policy for unprecedented fiscal expansion to combat recession, but interest rates have not risen as a result of rising public debt due to lax monetary policy (Feldstein, 2009). The global financial and economic crisis has brought unprecedented challenges to the coordination of fiscal and monetary policies on many issues, including the extent of public debt sustainability, the need for fiscal adjustment and inflationary effects at high debt levels (Blanchard et al., 2010; Cottarelli \& Viñals, 2010).

\section{Literature Review}

The first theoretical model addressed the need for fiscal and monetary policy coordination introduced by Sargent and Wallace (Sargent \& Wallace, 1981). They introduced the concept of fiscal policy dominance, which means that the central bank is unable to control money supply and inflation if fiscal policy is dominant. In the case of large budget deficit and high level of government debt, the central bank unable through a deflationary monetary policy to reduce inflation because of the real interest rate become higher than the rate of growth in the economy, resulting in an increase in the rate of public debt service and debt-to-output ratio and future budget deficit. Because of the limited capacity of financial markets, a large proportion of public debt is financed by issuance money, "seignorage", which will raise the rate of inflation in the future, therefore, The unpleasant monetarist arithmetic demonstrates the central bank's inability to control inflation if it is subject to fiscal policy and has had to finance the budget deficit, even if it is independent Therefore, wisdom requires a reduction in the level of debt, which reduces the real interest rate below the rate of growth and thus the central bank can control inflation.

In the 1990s, fiscal theory of price level gave fiscal policy an important role in macroeconomic stability. According 
to this theory, the general level of prices should increase in order to decrease the real value of government debt, which means that the general level of prices equals the present value of the future budget deficit with the current balance of government debt (Leeper, 1991; Sims, 1994; and Woodford, 1994, 1996).

Dixit and Lambertini analyzed the interaction between fiscal and monetary policies in case of different objectives, where the race between them ends to achieve results not optimal decline in output and price increases, due to a very deflationary fiscal policy and a very expansionary monetary policy and then even in the presence of monetary commitment The consequences of fiscal policy completely deny the benefits of monetary commitment, adding that these problems can be solved in a number of ways, including that the fiscal and monetary authorities have the same goal, give one policy a leadership role, or set constitutional constraints on fiscal policy (Dixit \& Lambertini, 2000, 2003). Coordination between monetary and monetary policies is also important in the case of monetary unions, especially the European Monetary Union, where there is one central bank and several independent fiscal policies Lambertini and Rovelli stressed the importance of coordinating fiscal and monetary policies because they improve monetary policy performance. Otherwise, the independent decisions of the financial and monetary authorities will lead to duplication of efforts or create negative externalities if they act in opposite directions (Lambertini \& Rovelli, 2004). Ghali and Monacelli pointed out that the fiscal position within the EU must be neutral in order for the ECB to achieve its goal of price stability (Galí \& Monacelli, 2008).

El-Refaie (2001) and Abdel-Haleem (2016) examined the extent of coordination between the fiscal and monetary policies in Egypt, where El-Refaie studied the coordination between the fiscal and monetary policies in Egypt in the 1990s. The coordination between the two policies in general, although it proved successful in 1997/98, was not as effective after that, as the deflationary fiscal policy became expansionary, resulting in an increase in the budget deficit target of $1 \%$ to GDP 4.2 percent in 1998/99. As for monetary policy, there has been deflation with large but short-term injections of liquidity, deepening the economic recession and exchange rate instability, as well as sharply reducing international reserves. Abdul Halim also studied the extent of coordination between the fiscal and monetary policies in Egypt in the period 1974-2015, where the ratio of money supply to GDP was used to express monetary policy and government consumption expenditure to express fiscal policy. The researcher relied on an Arabic methodology, Arby and Hanif (2010), who used to study the extent of coordination between the fiscal and monetary policies in Pakistan. The study concluded that coordination between the two policies was either absent or weak in Egypt during the period 1974-2015. The weak coordination resulted in a large fiscal deficit affecting monetary policy in its price stability goal.

\section{Methodology and Model Estimation}

This study examines to what extent the interaction of fiscal and monetary policies in Egypt during the period 1980-2016. It uses the ratio of money supply to the gross domestic product (GDP) as an indicator of monetary policy, surplus or deficit as an indicator of fiscal policy and inflation as a goal to reduce monetary policy. The methodology is based on both the VEC and Granger causality through Eviews 9.

$$
\text { Inflation }=\alpha+\beta 1 M 2+\beta 2 \text { Budget }+\varepsilon
$$

Where:

M2: The ratio of money supply to GDP;

Inflation: Consumer Price Index (CPI);

Budget: Budget surplus or deficit;

$\varepsilon$ : White-noise error term.

The data obtained from the World Bank website. Table 1 shows the descriptive statistics of the variables of the study. It is clear that the data of all the variables follows the natural distribution through the test of Jarque-Bera, where the null hypothesis was accepted. The data is distributed as normal distribution where prob> 0.05 for all study variables. Figure 1 shows the graph of the study variables. It shows that the budget deficit, the money supply, and all the inflation moves in one direction, as the increase in the budget deficit entails an increase in both money supply and inflation. This is evident during the 1980s in the last century until 1992 and from the period 2004 until the end of the study period. The period from 1992-2003 witnessed a decrease in the budget deficit as well as a decrease in both money supply and inflation. Therefore, the fiscal policy on monetary policy in Egypt during the study period was dominant. 
Table 1. Descriptive statistics for the variables of the study

\begin{tabular}{cccc}
\hline & BUDGET & M2 & INFLATION \\
\hline Mean & -6.4325 & 85.16022 & 11.26 \\
Median & -7.2 & 85.12438 & 10.81 \\
Maximum & 1.7 & 98.17599 & 23.87 \\
Minimum & -17.1 & 69.715 & 2.27 \\
Std. Dev. & 4.734371 & 7.922485 & 5.79 \\
Skewness & -0.06126 & 0.11558 & 0.22 \\
Kurtosis & 2.104159 & 1.977734 & 2.20 \\
Jarque-Bera & 1.226311 & 1.647693 & 1.24 \\
Probability & 0.541639 & 0.438741 & 0.54 \\
Sum & -231.57 & 3065.768 & 405.30 \\
Sum Sq. Dev. & 784.4993 & 2196.802 & 1173.28 \\
Observations & 36 & 36 & 36 \\
\hline
\end{tabular}

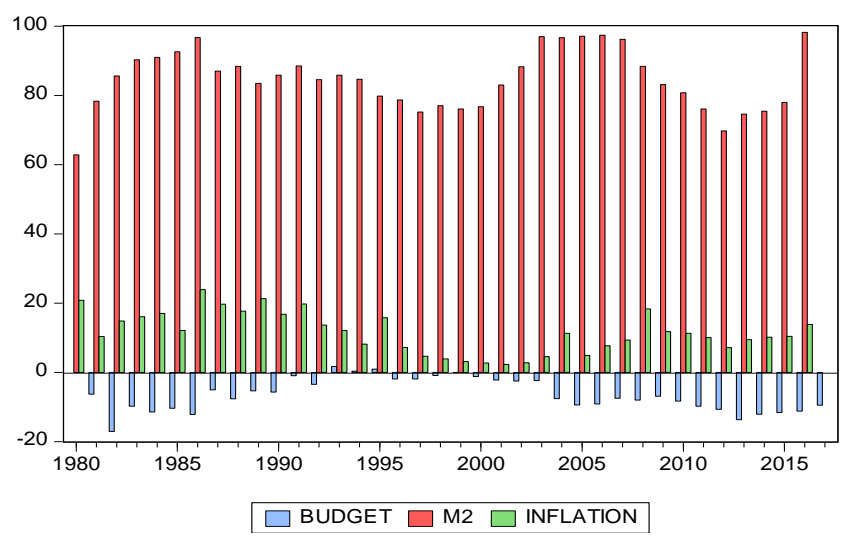

Figure 1. A diagram of the study variables

\subsection{Unit Root Test}

The following table 2 shows the results of the time series stability test will use the breakpoint unit root test will be use. It is clear that all the variables are stable in the first difference with a constant enabling us to carry out Co-integration of study variables.

Table 2. Summary of results of the Unit root test

\begin{tabular}{cccccc}
\hline \multicolumn{5}{c}{ Test Augmented Dickey Fuller (ADF) } \\
\hline variables & \multicolumn{3}{c}{ Level } & First Difference \\
\hline & Constant & Trend & Constant & Trend & Summery \\
INFLATION & -2.93 & -3.68 & $-9.95^{* * *}$ & -3.68 & I $(1)$ \\
M2 & -4.01 & -4.51 & $-4.98^{* *}$ & -4.83 & I $(1)$ \\
BUDGET & -2.73 & -3.69 & $-13.69^{* *}$ & -3.69 & I $(1)$ \\
\hline
\end{tabular}

Note. 1) For ADF and PP tests, ***, ** and * denote rejection of a unit root hypothesis based on Mackinnon (1991) critical values at $10 \%, 5 \%$ and1percentage respectively.

\subsection{Co-Integration Test}

From Table 4 which shows the results of Co- integration test, it is clear that there is one model for the Cointegration of study variables that enables us to use the Vector error correction model to estimate the long-term relationship between money supply, budget deficit, and inflation. 
Table 4. The result of Cointegration test

\begin{tabular}{|c|c|c|c|c|}
\hline Hypothesized & & Trace & 0.05 & \\
\hline No. of $\mathrm{CE}(\mathrm{s})$ & Eigenvalue & Statistic & Critical Value & Prob.** \\
\hline None * & 0.765407 & 62.11415 & 29.79707 & 0.0000 \\
\hline At most 1 & 0.174248 & 12.81749 & 15.49471 & 0.1217 \\
\hline At most $2 *$ & 0.169331 & 6.307813 & 3.841466 & 0.0120 \\
\hline \multicolumn{5}{|c|}{ Trace test indicates 1 cointegrating eqn(s) at the 0.05 level } \\
\hline \multicolumn{5}{|c|}{ Unrestricted Cointegration Rank Test (Maximum Eigenvalue) } \\
\hline Hypothesized & & Max-Eigen & 0.05 & \\
\hline No. of $\mathrm{CE}(\mathrm{s})$ & Eigenvalue & Statistic & Critical Value & Prob.** \\
\hline None * & 0.765407 & 49.29665 & 21.13162 & 0.0000 \\
\hline At most 1 & 0.174248 & 6.509681 & 14.26460 & 0.5487 \\
\hline At most $2 *$ & 0.169331 & 6.307813 & 3.841466 & 0.0120 \\
\hline \multicolumn{5}{|c|}{ Max-eigenvalue test indicates 1 cointegrating eqn(s) at the 0.05 level } \\
\hline \multicolumn{5}{|c|}{$*$ denotes rejection of the hypothesis at the 0.05 level } \\
\hline \multicolumn{5}{|c|}{ **MacKinnon-Haug-Michelis (1999) p-values } \\
\hline
\end{tabular}

\subsection{Vector Error Correction (VEC)}

The results of the long-term relationship between inflation, money supply, and the budget deficit were estimated in the equation (2) and in Table 5.

$$
\text { Inflation }=-49.4+0.50 \mathrm{M} 2+0.81 \text { Budget }
$$

It is clear to us through the estimated relationship in the model that there is a long-term significant relation between inflation, money supply and the budget deficit in Egypt, and that both monetary policy and fiscal policy, in the long run, are responsible for increasing inflation rates in Egypt. The increase in the budget deficit by $1 \%$ has an increase in the inflation rate of $0.81 \%$, indicating that the monetary policy is not targeted for inflation in the long term. However, fiscal policy is also dominant on the monetary policy as the financing of the change in $1 \%$ of the budget deficit results in an inflationary effect of $0.81 \%$ of that change in this deficit, either directly or indirectly.

Table 5. VEC estimates

\begin{tabular}{|c|c|c|c|}
\hline Cointegrating Eq: & CointEq1 & & \\
\hline INFLATION(-1) & 1.000000 & & \\
\hline \multirow{3}{*}{$\mathrm{M} 2(-1)$} & 0.508236 & & \\
\hline & $(0.14243)$ & & \\
\hline & [ 3.56822] & & \\
\hline \multirow[t]{3}{*}{ BUDGET(-1) } & 0.810770 & & \\
\hline & $(0.35250)$ & & \\
\hline & [ 2.30004] & & \\
\hline $\mathrm{C}$ & -49.40277 & & \\
\hline Error Correction: & D(INFLATION) & $\mathrm{D}(\mathrm{M} 2)$ & $\mathrm{D}$ (BUDGET) \\
\hline \multirow[t]{3}{*}{ CointEq1 } & -0.005027 & -0.526284 & -0.017666 \\
\hline & $(0.00099)$ & $(0.22998)$ & $(0.09974)$ \\
\hline & {$[-5.06249]$} & {$[-2.28835]$} & {$[-0.17713]$} \\
\hline \multirow[t]{3}{*}{ D(INFLATION(-1)) } & 1.848909 & -1.299455 & -7.577498 \\
\hline & $(0.03892)$ & $(9.01393)$ & (3.90906) \\
\hline & [ 47.5107] & {$[-0.14416]$} & {$[-1.93845]$} \\
\hline \multirow[t]{3}{*}{ D(INFLATION(-2)) } & -0.911201 & 0.667512 & 7.073000 \\
\hline & $(0.03693)$ & $(8.55398)$ & $(3.70959)$ \\
\hline & {$[-24.6738]$} & [ 0.07804$]$ & [ 1.90668$]$ \\
\hline \multirow[t]{3}{*}{$\mathrm{D}(\mathrm{M} 2(-1))$} & $-2.84 \mathrm{E}-06$ & 0.311126 & 0.166641 \\
\hline & $(0.00115)$ & $(0.26688)$ & $(0.11574)$ \\
\hline & {$[-0.00246]$} & [ 1.16581$]$ & [ 1.43984$]$ \\
\hline \multirow[t]{3}{*}{$\mathrm{D}(\mathrm{M} 2(-2))$} & -0.001352 & 0.415783 & 0.054022 \\
\hline & $(0.00120)$ & $(0.27898)$ & $(0.12098)$ \\
\hline & {$[-1.12230]$} & [ 1.49038] & [ 0.44653] \\
\hline \multirow[t]{3}{*}{ D(BUDGET(-1)) } & 0.001441 & 0.665056 & -0.388302 \\
\hline & $(0.00210)$ & $(0.48741)$ & $(0.21137)$ \\
\hline & {$[0.68472]$} & [ 1.36447$]$ & {$[-1.83703]$} \\
\hline
\end{tabular}




\begin{tabular}{lrrr}
\hline D(BUDGET(-2)) & -0.000657 & 0.357120 & 0.048802 \\
& $(0.00165)$ & $(0.38163)$ & $(0.16550)$ \\
C $[-0.39877]$ & {$[0.93578]$} & {$[0.29487]$} \\
& -0.010673 & 0.199328 & -0.003810 \\
& $(0.00401)$ & $(0.92804)$ & $(0.40246)$ \\
R-squared & {$[-2.66389]$} & {$[0.21478]$} & {$[-0.00947]$} \\
Adj. R-squared & 0.999257 & 0.297703 & 0.339826 \\
Sum sq. resids & 0.999049 & 0.101060 & 0.154978 \\
S.E. equation & 0.012458 & 668.3721 & 125.6997 \\
F-statistic & 0.022323 & 5.170579 & 2.242317 \\
Log likelihood & 4804.547 & 1.513924 & 1.838402 \\
Akaike AIC & 83.22681 & -96.46254 & -68.89187 \\
Schwarz SC & -4.559201 & 6.331063 & 4.660113 \\
Mean dependent & -4.196411 & 6.693853 & 5.022903 \\
S.D. dependent & -0.158931 & 0.239708 & -0.043030 \\
Determinant resid covariance (dof adj.) & 5.453480 & 2.439287 \\
Determinant resid covariance & & 0.059223 & \\
Log likelihood & & 0.025750 & \\
Akaike information criterion & & -80.09588 & \\
Schwarz criterion & & 6.490659 & \\
\hline
\end{tabular}

\subsection{Test the Quality of the Model}

In order to test the quality of the model, the researcher tested the normal distribution of the Residual, which is shown in Table 6, where it was found that the Residual is distributed naturally. The null hypothesis is assumed that the Residual follow the natural distribution. The researcher tested the residual serial correlation; the results of this test in the table 7 indicated that there is no residual serial correlation between the errors in order to accept the null hypothesis that suggests the independence of random errors. The Heteroskedasticity test presented in Table 8 has been accepted for the null hypothesis, which assumes the homoscedasticity of the study variables and rejects the Heteroskedasticity. Also Wald Test results in table 9 illustrate the significance of all study variables. From previous model quality tests, it is clear that the model is acceptable and can be relied on.

Table 6. VEC residual normalitytests result

\begin{tabular}{lcclc}
\hline Component & Skewness & Chi-sq & df & Prob. \\
\hline 1 & -0.245389 & 0.331187 & 1 & 0.5650 \\
2 & 0.610697 & 2.051230 & 1 & 0.1521 \\
3 & -0.312134 & 0.535852 & 1 & 0.4642 \\
Joint & & 2.918269 & 3 & 0.4044 \\
\hline Component & Kurtosis & Chi-sq & df & Prob. \\
\hline 1 & 2.411281 & 0.476561 & 1 & 0.4900 \\
2 & 3.857444 & 1.010913 & 1 & 0.3147 \\
3 & 2.973226 & 0.000986 & 1 & 0.9750 \\
Joint & & 1.488460 & 3 & 0.6849 \\
\hline Component & Jarque-Bera & Df & Prob. & \\
\hline 1 & 0.807747 & 2 & 0.6677 & \\
2 & 3.062143 & 2 & 0.2163 & \\
3 & 0.536838 & 2 & 0.7646 & \\
Joint & 4.406728 & 6 & 0.6218 & \\
\hline
\end{tabular}

Table 7. VEC residual serial correlation LM tests

\begin{tabular}{lcc}
\hline Lags & LM-Stat & Prob \\
\hline 1 & 15.85729 & 0.0699 \\
2 & 7.804346 & 0.5540 \\
3 & 9.757777 & 0.3704 \\
\hline robs from chi-square with 9 df. & \\
\hline
\end{tabular}


Table 8 . Heteroskedasticity Test

\begin{tabular}{|c|c|c|c|c|c|}
\hline \multicolumn{6}{|c|}{ Joint test: } \\
\hline Chi-sq & $\mathrm{df}$ & Prob. & & & \\
\hline 91.26130 & 84 & 0.2756 & & & \\
\hline \multicolumn{6}{|c|}{ Individual components: } \\
\hline Dependent & $\mathrm{R}$-squared & $\mathrm{F}(14,18)$ & Prob. & Chi-sq(14) & Prob. \\
\hline res1*res1 & 0.546782 & 1.551139 & 0.1886 & 18.04379 & 0.2048 \\
\hline res $2 *$ res 2 & 0.444292 & 1.027938 & 0.4701 & 14.66165 & 0.4017 \\
\hline res $3 *$ res 3 & 0.640507 & 2.290753 & 0.0499 & 21.13674 & 0.0982 \\
\hline res $2 *$ res 1 & 0.418732 & 0.926199 & 0.5511 & 13.81816 & 0.4633 \\
\hline res3*res 1 & 0.631435 & 2.202721 & 0.0583 & 20.83736 & 0.1059 \\
\hline res $3 *$ res 2 & 0.569657 & 1.701936 & 0.1434 & 18.79868 & 0.1728 \\
\hline
\end{tabular}

Table 9. Wald Test result

\begin{tabular}{lccc}
\hline Test Statistic & Value & df & Probability \\
\hline F-statistic & 8575.164 & $(3,25)$ & 0.0000 \\
Chi-square & 25725.49 & 3 & 0.0000 \\
\hline Null Hypothesis: $\mathrm{C}(1)=\mathrm{C}(2)=\mathrm{C}(3)=0$ & & \\
Null Hypothesis Summary: & & \\
\hline Normalized Restriction $(=0)$ & Value & Std. Err. \\
\hline $\mathrm{C}(1)$ & -0.005027 & 0.000993 \\
$\mathrm{C}(2)$ & 1.848909 & 0.038916 \\
$\mathrm{C}(3)$ & -0.911201 & 0.036930 \\
\hline Restrictions are linear in coefficients. & & \\
\hline
\end{tabular}

\section{Causality Test}

The following table examines the Granger causality test to identify the causal relationship between the variables of the study to determine the causal direction between fiscal and monetary policy and inflation in Egypt during the period 1980-2016. The following table 3 presents the results of the test.

Table 3. Results of the causality test

\begin{tabular}{|c|c|c|c|}
\hline Direction of causation & laged periods & F-Statistic & Prob. \\
\hline Inflation $\leftarrow$ Budget Deficit & 2 & 5.84684 & 0.0074 \\
\hline Budget Deficit $\leftarrow$ Money Supply & & 12.8620 & 0.0001 \\
\hline Budget Deficit $\leftarrow$ Inflation & 3 & 5.77154 & 0.0037 \\
\hline Inflation $\leftarrow$ Budget Deficit & 4 & 2.95600 & 0.0416 \\
\hline Budget Deficit $\leftarrow$ Money Supply & & 6.37725 & 0.0013 \\
\hline Money Supply $\leftarrow$ Inflation & & 8.78976 & 0.0002 \\
\hline Budget Deficit $\leftarrow$ Money Supply & 5 & 3.83941 & 0.0134 \\
\hline Inflation $\leftarrow$ Money Supply & & 7.91015 & 0.0003 \\
\hline Inflation $\leftarrow$ Budget Deficit & 6 & 3.01543 & 0.0340 \\
\hline Budget Deficit $\leftarrow$ Money Supply & & 4.61452 & 0.0059 \\
\hline Inflation $\leftarrow$ Money Supply & & 4.95437 & 0.0037 \\
\hline Budget Deficit $\leftarrow$ Money Supply & 7 & 8.86319 & 0.0003 \\
\hline Inflation $\leftrightarrow$ Money Supply & & 7.26702 & 0.0007 \\
\hline Budget Deficit $\leftarrow$ Money Supply & 8 & 7.59988 & 0.0015 \\
\hline Inflation $\leftarrow$ Money Supply & & 10.6050 & 0.0002 \\
\hline Budget Deficit $\leftarrow$ Money Supply & 9 & 6.68063 & 0.0068 \\
\hline Budget Deficit $\longleftarrow$ Inflation & & 3.98104 & 0.0323 \\
\hline Inflation $\leftarrow$ Money Supply & & 5.95803 & 0.0069 \\
\hline Budget Deficit $\leftarrow$ Money Supply & 10 & 8.75745 & 0.0136 \\
\hline Inflation $\leftarrow$ Money Supply & & 5.72751 & 0.0223 \\
\hline
\end{tabular}

It is noted from the previous table that there is a one-way causal relationship of inflation to both the budget deficit 
and the money supply, which affects the budget deficit in the second lag period and then feed the budget deficit inflation in the third year, which in turn feeds the budget deficit in the fourth and sixth year, The causal link between inflation and money supply has concluded that there is a one-way causal relationship of money supply to inflation after four lags and then inflation affects the money supply from the fifth to the tenth deceleration. As for the relationship of the budget deficit to the money supply, a causal effect of one of the budget deficit on money supply from the second to the tenth year except for the third year, which also confirms the dominance of fiscal policy on monetary policy in Egypt during the study phase?

\subsection{Conclusion}

This study examines the extent of coordination between the monetary and fiscal policies in Egypt during the period 1980-2017 towards price stability as a target for monetary policy and relied on money supply as a variable representing monetary policy decisions and surplus or budget deficit as a variable that reflects policy decisions Finance and inflation as a variable expresses a goal of monetary policy trying to target or control and cooperate in that fiscal policy through the coordination of decisions between the financial and monetary authorities. It has been adopted in its methodology on error correction vector and tests the causality of Grange. The study concludes that there is a significant correlation between the money supply and surplus or budget deficit on one hand and inflation on the other. Monetary policy is dominant in monetary policy as a change of $10 \%$ of the budget deficit results in an increase in the rate of inflation of $8.1 \%$, which means that fiscal policy impedes monetary policy in its ability to reduce inflation in the long term. As for the test of Granger causality, it stressed the existence of causal relationship to one direction of inflation against both the budget deficit and the money supply, which affects the budget deficit in the second slowdown and then feeds the budget deficit inflation in the third year, which in turn feeds the budget deficit in the fourth year And the causal relationship between inflation and money supply has concluded that there is a one-way causal relationship of money supply to inflation after four slows and then inflation affects the money supply from the fifth to the tenth slowdown. As for the relationship of the budget deficit to money supply, there may be a one-way causal relationship between the budget deficit and the money supply from the second to the tenth year, with the exception of the third year, which also confirms the dominance of fiscal policy on monetary policy in Egypt during the period was considered.

\section{References}

Abdel-Haleim, S. (20016). Coordination of Monetary and Fiscal Policies: The Case of Egypt. International Review of Research in Emerging Markets and the Global Economy (IRREM), 2(4), 933-954. http://globalbizresearch.org/files/df606_irrem_sahar-mohamed-abdel-haleim-416692.pdf

Alesina, A., \& Tabellini, G. (1987). Rules and Discretion with Noncoordinated Monetary and Fiscal Policies. Economic Inquiry, 25(4), 619-30. https://doi.org/10.1111/j.1465-7295.1987.tb00764.x

Arby, M., \& Hanif, M. (2010). Monetary and Fiscal Policies Coordination: Pakistan's Experience. State.Bank of $\begin{array}{lllll}\text { Pakistan } & \text { (SBP) } & \text { Research } & \text { Bulletin, } & \text { 6(1), }\end{array}$ https://www.researchgate.net/publication/46446039_Monetary_and_fiscal_policies_coordination_-_Pakista n's_experience

Beetsma, R. M. W. J., Debrun, X., \& Klaassen, F. (2001). Is fiscal policy coordination in EMU desirable? $\begin{array}{lllll}\text { Swedish Economic } & \text { Policy } & \text { Review, } & \text { 8, } & \text { 57-98. }\end{array}$ http://citeseerx.ist.psu.edu/viewdoc/download?doi=10.1.1.113.3070\&rep=rep1\&type=pdf

Begg, I., Hodson, D., \& Maher, I. (2003). Economic policy coordination in the European Union. National Institute Economic Review, 183(1), 66-77. https://doi.org/10.1177/0027950103183001462

Bennett, H., \& Loayza, N. (2002). Policy Biases When the Monetary and Fiscal Authorities Have Different Objectives. In N. Loayza, \& K. Schmidt-Hebbel (Eds.), Monetary Policy: Rules and Transmission Mechanism (pp. 299-330). Santiago: Central Bank of Chile.

Blanchard, O., Dell'Ariccia, G., \& Mauro, P. (2010). Rethinking Macroeconomic Policy. In O. Blanchard, \& I. SaKong (Eds.), Reconstructing World Economy (pp. 25-40). Washington D.C.: International Monetary Fund and Korea Development Institute. https://www.imf.org/external/pubs/ft/spn/2010/spn1003.pdf

Bryson, J. H. (1994). Macroeconomic stabilization trough monetary and fiscal policy coordination: Implication for European Monetary Union. Open Economies Review, 5(4), 307-326. https://doi.org/10.1007/BF01000717

Calmfors, L. (2003). Fiscal Policy to Stabilise the Domestic Economy in the EMU: What Can We Learn from Monetary Policy?. CESifo Economic Studies, 49(3), 319-353. https://doi.org/10.1093/cesifo/49.3.319 
Cottarelli, C., \& Viñals, J. (2010). A Strategy for Renormalizing Fiscal and Monetary Policies in Advanced Economies. In O. Blanchard, \& I. SaKong (Eds.), Reconstructing World Economy (pp. 3-22). Washington D.C.: International Monetary Fund and Korea Development Institute. https://doi.org/10.5089/9781455278459.004

Dixit, A., \& Lambertini, L. (2003). Interactions of Commitment and Discretion in Monetary and Fiscal Policies. American Economic Review, 93, 1522-1542. https://doi.org/10.1257/000282803322655428

Dixit, A., \& Lambertini, L. (2000). Fiscal Discretion Destroys Monetary Commitment. Princeton University and UCLA (mimeo). https://doi.org/10.2139/ssrn.232654

Elhendawy, E. (2015). Sterilization and Inflation in the Long-Term Empirical Evidence from Egypt. Applied Economics and Finance, 2(2), 68-78. https://doi.org/10.11114/aef.v2i2.757

Elhendawy, E. (2014). The Relationship between Budget Deficit and Current Account Deficit in Egypt. International Journal of Economics and Finance, 6(3), 169-178. https://doi.org/10.5539/ijef.v6n3p169

El-Refaie, F. (2001). The Coordination of Monetary and Fiscal Policies in Egypt. The Egyptian Center for Economic Studies (ECES), working paper http://eces.org.eg/MediaFiles/Uploaded_Files/\%7B8A6AEA20-08B3-4659-9840-AAF4BE74A3F2\%7D_E CESWP54e.pdf

Eusepi, S., \& Preston, B. (2008). Stabilizing Expectations under Monetary and Fiscal Policy Coordination. NBER Working Paper 14391, National Bureau of Economic Research. https://doi.org/10.3386/w14391

Feldstein, M. S. (2009). Rethinking the Role of Fiscal Policy. NBER Working Paper 14684, National Bureau of Economic Research. https://doi.org/10.3386/w14684

Galí, J., \& Monacelli, T. (2008). Optimal monetary and fiscal policy in a currency union. Journal of International Economics, 76, 116-132. https://doi.org/10.1016/j.jinteco.2008.02.007

Kamal, M. (2010). The Theoretical Framework for the Coordination of Fiscal and Monetary Policies. MPRA paper (in Arabic). https://mpra.ub.uni-muenchen.de/26856/1/MPRA_paper_26856.pdf

Kuttner, K. N. (2002). The Monetary-Fiscal Policy Mix: Perspectives from the U.S. Paper presented at the Conference on: The Monetary Policy Mix in the Environment of Structural Changes, sponsored by the National Bank of Poland, 24-25. https://pdfs.semanticscholar.org/6d01/3a3eb39c6f31e0cef3d50fa8419e9f655c28.pdf

Lambertini, L., \& Rovelli, R. (2004). Monetary and fiscal policy coordination and macroeconomic stabilization. A theoretical analysis. Dipartimento di Scienze Economiche, Bologna: Universita di Bologna. https://pdfs.semanticscholar.org/9b9e/8153b0bfc41a989a4f18b5cca99a4f090248.pdf

Lee, J. Y. (1996). Implications of a Surge in Capital Inflows: Available Tools and Consequences for the Conduct of Monetary Policy. IMF Working Paper, International Monetary Fund. https://doi.org/10.5089/9781451847345.001

Leeper, E. M. (1991). Equilibria under 'Active' and 'Passive' Monetary and Fiscal Policies. Journal of Monetary Economics, 27(1), 129-147. https://doi.org/10.1016/0304-3932(91)90007-B

Sargent, T. J., \& Wallace, N. (1981). Some Unpleasant Monetarist Arithmetic. Federal Reserve Bank of Minneapolis Quarterly Review, 5(1), 1-17. https://www.minneapolisfed.org/research/qr/qr531.pdf

Sims, C. A. (1994). A Simple Model for Study of the Determination of the Price Level and the Interaction of Monetary and Fiscal Policy. Economic Theory, 4, 381-399. https://doi.org/10.1007/BF01215378

Woodford, M. (1994). Monetary Policy and Price Level Determinacy in a Csh-in-advance Economy. Economic Theory, 4, 345-380. https://doi.org/10.1007/BF01215377

Woodford, M. (1996). Control of the Public Debt: A Requirement for Price Stability. NBER Working Paper No. 5684, National Bureau of Economic Research. https://doi.org/10.3386/w5684

\section{Copyrights}

Copyright for this article is retained by the author(s), with first publication rights granted to the journal.

This is an open-access article distributed under the terms and conditions of the Creative Commons Attribution license (http://creativecommons.org/licenses/by/4.0/). 